\title{
The electoral effects of the descriptive representation of ethnic minority groups in Australia and the UK
}

\author{
Joshua N Zingher \\ University of Oklahoma, USA \\ Benjamin Farrer \\ Hobart and William Smith Colleges, USA
}

\begin{abstract}
In this article we assess the electoral effects of the nomination of ethnic minority candidates. We argue that descriptive representation is an important factor in how parties in SMD systems establish their coalitions over multiple elections. We demonstrate this by showing that descriptive representation has a consistent effect on voting behavior, and thus that parties can rely on descriptive representation to win over specific segments of the voting population. Previous studies have been limited to single election years and single countries, but we collect original data from multiple election cycles in Australia and the UK to test our argument. We find that descriptive representation is consistently associated with a 10-percentage point bump in support from ethnic minority independents and Labour supporters. We conclude by highlighting the importance of this finding for party competition.
\end{abstract}

\section{Keywords}

candidate nomination, descriptive representation, ethnic minority, voting behavior

What electoral consequences is a party likely to face when it nominates an ethnic minority candidate to stand for higher office? Many scholars have argued that the electoral effects of descriptive representation are both diverse and politically important. Previous studies have shown that the descriptive representation of minority groups leads to shifts in vote choice, increased turnout (Barreto et al., 2004; Bobo and Gilliam,1990; Gay, 2001; Jones, 2014; Mansbridge, 1999; Pantoja et al., 2001; Tate, 2003; Whitbey, 2007), and even increased trust in political institutions among group members (Scherer and Curry, 2010). There is a considerable amount of evidence that there is a tighter connection between the electors and the elected when they both share the same ethnic background (Pitkin, 1972). We argue that if these effects are consistent, then nominating ethnic minority candidates can become an important tool political parties use to gain votes, making descriptive representation an important component of a party's overall electoral strategy. In this article we establish that the electoral effects of descriptive representation are indeed consistent across a variety of electoral contexts.
Many previous studies that examine the electoral consequences of descriptive representation are limited to one country or one election (Dancygier and Saunders, 2006). This makes it difficult to separate short-term, electionspecific factors from the effects of descriptive representation, and so hinders our ability to draw generalizable conclusions about what the long-term effects of descriptive representation actually are. Using data from the UK and Australia, spanning multiple elections, we introduce a new and comparative empirical assessment of the effects of descriptive representation on voting behavior in an effort to establish the necessary empirical baseline. ${ }^{1}$

This article is organized into four sections. In the first section, we go over previous theoretical literature on descriptive representation, highlighting in particular the

\section{Corresponding author:}

Benjamin Farrer, Department of Political Science, Hobart and William Smith Colleges, Geneva, NY, I4456, USA.

Email: benjaminfarrer@gmail.com 
potential trade-off between increasing ethnic minority participation at the cost of a backlash from some ethnic majority voters. We also emphasize the need for empirical benchmarks for both phenomena. In the second section, we introduce cross-country empirical evidence that descriptive representation has a consistent effect. We show that there is a 10-percentage point bump in support among ethnic minority voters when center-left parties nominate an ethnic minority candidate. In some instances we find that the nomination of minority candidates produces a backlash of similar magnitude from ethnic majority voters. We discuss the implications of our analysis for party competition in the third section. The fourth section concludes and suggests some avenues for future research.

\section{I.I The relationship between ethnicity and voting behavior}

Voters want to cast ballots for political parties that represent their interests. The classic Downsian model assumes that representation takes place along a single left-right dimension. Voters cast their ballot for the party closest to the voter's own position along this dimension (Adams et al., 2005; Downs, 1957; Hinich and Munger,1997; Jessee, 2009; Merrill and Grofman, 1999). However, the voting behavior of many ethnic minority groups often systematically violates this basic assumption of spatial theories of voting. Members of ethnic and racial minority groups repeatedly support social democratic parties in spite of the fact that many group members hold conservative policy positions - ethnic minorities support social democratic parties at a higher rate than their ideological self-placement would suggest (Adams et al., 2005). In many cases, this support is consistent over time, and these ethnic minority groups become an important group in the party coalition. This in turn can lead to changes in policy, in party systems, and in election outcomes. This electoral loyalty is both important and widespread.

For example, Dancygier and Saunders (2006; also see Saggar, 2000) find that visible minorities in the UK and Germany vote disproportionately for Labour despite holding ideological positions that are no different to those of the rest of the population (when controlling for age, income, etc). Dawson (1994) noted a similar connection between the Democratic Party and African Americans in the United States-African Americans support the Democratic Party at a higher rate than what would be expected on the basis of left/right ideology alone. Ethnic minority groups are frequently socially and economically marginalized, so it is not surprising that most of these groups support parties that favor the greater redistribution of wealth and the correction of social discrimination. The same pattern of ethnic minority voting behavior has been demonstrated in a number of Western countries (Dancygier and Saunders, 2006-Britain and Germany; Geddes, 2003; Saggar, 2000; Sobolewska, 2005-Britain;
Zingher and Thomas, 2012-Australia). However, many ethnic and racial minority groups support social democratic parties at a higher rate than would be expected even when taking into account the effects of economic marginalization. What explains the gap between ethnic minority voters' economic and social status and voting behavior?

Dawson (1994; also see Chong, 1991; Chong and Kim, 2006; Chong and Rogers, 2005; Dancygier and Saunders, 2006; Simon and Klandermans, 2001) first introduced the term "linked fates" to explain the psychological microfoundations of African American bloc voting in the United States. Dawson's fundamental claim was that African Americans in the United States viewed their social position as inherently linked with that of other African Americans. Middle class African Americans vote in much the same fashion as poor African Americans - the economic cleavage that crosscuts many other social groups in the United States does not affect African Americans in a comparable way.

If there is a gap between ethnic minorities' ideological positions and voting behavior it is the result of appeals to voters along group lines. The importance of group membership has the effect of introducing a second consideration that shapes voting behavior along with an individual's ideological position. The introduction of this second consideration has implications for party competition.Along with offering the electorate a choice on the left-right economic dimension, parties must also choose to try and appeal to voters' ethnic group attachments. The key question here is: how do parties attempt to appeal to voters' group attachments? Or in other words: how can a party come to be viewed as representing a specific group's interests, whatever they may be? We argue that one important way that parties appeal to voters' ethnic group attachments is through the nomination of candidates from ethnic minority backgrounds. In the next subsection we explain the justification for this claim.

\section{I.2 Descriptive representation as a tool for increasing support in minority communities}

The nomination of descriptively representative candidates is one relatively immediately malleable tool that political parties have at their disposal that is capable of signaling a credible commitment to group interests. Groups of all types often view descriptive representation as a credible means for incorporation of minority interests in politics. For members of ethnic minority groups, sharing a common background and life experiences with their representative is important for assuring quality representation (Bird et al., 2010, Bloemraad, 2006; Preuhs, 2007). Higher levels of voter turnout and lower levels of political alienation among members of a minority group are found when minority 
groups are represented descriptively (Mansbridge 1999; Pantoja et al., 2001; Whitbey, 2007). The potential mobilizing effects of descriptive representation have been shown to be particularly strong amongst voters that might otherwise not be engaged in the electoral process (Clark, 2014: 324-325). Descriptive representation can be an attractive option for political parties that are looking to consolidate a base of electoral support, given descriptive representation's potentially dramatic influence on voters' perceptions of party commitment to representing a group's interest. However, nominations are a scarce resource. If descriptive representation is an effective electoral tool then nominating minority candidates must gain the party more votes than it costs them. The key question here is: what are the electoral effects of nominating an ethnic minority candidate?

Prior studies have provided evidence that suggests that the nomination of ethnic minority candidates is associated with an increase in ethnic minority turnout and support for the co-ethnic candidate. In an analysis of the 2010 British general election, Fisher et al. (2014: 18) found that those of Pakistani and Bangladeshi heritage were more likely to support co-ethnic candidates, while those of West Indian and African heritage were not. However, other studies that examine the electoral effects of nominating ethnic minority candidates have produced different results depending on the election year and the party doing the nominating (Curtice et al., 2005; Mortimore, 2002; Stegmaier et al., 2013). It is likely that different parties generate different levels of increased ethnic minority support from the nomination of ethnic minority candidatessome parties might stand to gain more than others. Parties on the left generally have a head start in attracting the support of minority groups due to the left's longstanding association with economically marginalized groups. Heath et al. (2013: Table 5.3) found that the vast majority of ethnic minorities in Britain perceived the Labour Party as better representing the interests of ethnic minorities. Similar sentiments have been observed in the Australian case as well (Zingher and Thomas, 2012: 382). It is possible that a greater degree of policy congruence makes descriptive representation a more effective electoral tool for parties on the left than parties on the right - which are capable of offering descriptive representation but lack the reputation for representing the interests of the economically and socially marginalized (Budge and Farlie, 1983; Griffin and Keane, 2006).

Gaining the votes of visible minorities is undoubtedly desirable, but political parties wishing to tap into the potential electoral power of immigrant communities often pay significant costs in the form of the loss of other groups of voters (Bird et al., 2010; Dancygier, 2010: 183-194). Some voters view visible minorities with unease or enmity (Wood et al., 2009), as they are thought to be sources of competition over jobs and social welfare resources (Ford,
2011; Scheve and Slaughter, 2001). Fisher et al. (2014) demonstrated that while the nomination of minority candidates can spur co-ethnic voting, whites were less likely to support minority candidates-especially Muslims. Because natives' attitudes towards immigrants are often unfavorable, incorporating immigrants into a political party carries a significant electoral risk, especially when placing ethnic minorities in highly visible positions on the ballot. Anti-immigrant parties have been successful in many mature democracies and could conceivably make considerable electoral gains if the major parties engage in descriptive representation (Arzheimer and Carter, 2006; Ezrow, 2010; Franzmann, 2011; Golder, 2003; Hug, 2001; Meguid, 2010; Mudde, 2007; Norris, 2005).

It is this dynamic that contributes to the important longterm effect that descriptive representation has on party competition. Dancygier articulates this process in her analysis of the decisions that Labour and the Conservatives must make when deciding how aggressively to court the ethnic minority vote, particularly through nominating minority candidates. Labour targeted South Asian immigrant voters and eventually positioned South Asian candidates on the Labour Party ballot. The result of this was an initial loss of white voters but a subsequent domination of several electoral districts on the strength of South Asian turnout (Dancygier, 2010: 202-207; Saggar, 2000). The story told by Dancygier parallels the story of immigrant political participation in New Deal era United States where the Democratic and Republican parties were making the same calculations when deciding how to approach recent Southern and Eastern European immigrants (Andersen, 1979; Wolfinger, 1965). Managing this trade-off is very important for the leaders of political parties, who must decide whether they have more to gain from nominating ethnic minority candidates, or are likely to lose in the long run due to an ethnic majority backlash. Because this electoral calculus is likely of considerable consequence, we seek to establish exactly what the underlying parameters of this tradeoff actually are.

Most existing studies are limited by the fact that they examine only one election in one country. It is difficult to disentangle the general relationship between ethnic minority candidacy and voting behavior from other shortterm electoral forces. This problem is made worse because there have been a limited number of ethnic minority candidates in British and Australian elections, meaning there might be significant year-to-year variance that arises as the product of small sample size. As a result, different studies have produced different results, depending on the specific electoral context. It is our goal to construct an analysis that spans both multiple elections and multiple countries in order to establish whether ethnic minority candidacy has a consistent effect on both ethnic minority and white voting behavior. We develop this basic set of expectations into a set of testable hypotheses in the next subsection. 


\section{I.3 Empirical implications}

The real question here is: what is the effect of descriptive representation on individual-level voting behavior? The existing literature on the nomination of ethnic minority candidates suggests that descriptive representation might have a twofold effect on voting behavior. Firstly, there is evidence that suggests that the nomination of ethnic minority candidates is likely associated with an increase in support among ethnic minority voters within the district. This expectation leads to the following hypothesis:

H1: The nomination of ethnic minority candidates is associated with an increase in electoral support from ethnic minority voters within the district. This increase in support can come both from an increase in turnout and from attracting voters who might otherwise support rival parties.

From a party's perspective, the nomination of ethnic minority candidates might be a desirable electoral strategy if descriptive representation produces a significant bump in electoral support from minority voters. However, this is assuming there are no electoral costs associated with placing ethnic minority candidates on the ballot. There is considerable evidence in the literature that the nomination of ethnic minority candidates is associated with a drop in support among non-minorities. This leads to a second hypothesis:

H2: The nomination of ethnic minority candidates is associated with a decrease in electoral support from non-ethnic minority candidates within the district. This decrease in support can come from both a decrease in turnout and from losing voters to other rival parties.

In the section below, we present a comprehensive assessment of the evidence so far. We estimate the effect of descriptive representation in multiple years and multiple countries, in order to establish whether descriptive representation can indeed have the important role that we hypothesize in assembling and maintaining party coalitions.

\section{I Research design, data, model specification, and results}

Our main hypothesis is that, all else equal, ethnic minority voters are more likely to vote for an ethnic minority candidate than for a non-ethnic minority candidate. If a consistent effect emerges, across multiple elections, this suggests that descriptive representation plays an important role in how parties cultivate long-term support. We test this hypothesis in this section using electoral and candidate data from the UK and Australia in an effort to conduct a comprehensive analysis of how descriptive representation affects voting behavior in the context of single member district elections. The comprehensiveness of the analysis is not just reflected in our sample size, but also in the range of subsamples we examine: we estimate the effect of descriptive representation on partisans and independents, on vote choice and turnout, on white voters and ethnic minority voters, and when two or more parties both run ethnic minority candidates. ${ }^{2}$

We use a combination of individual level survey data and candidate level data in order to test our hypotheses. Our individual level data comes from multiple iterations of two major public opinion surveys: the British Election Study (BES) and the Australian National Election Survey (ANES). Our data from the UK spans 1983 through 2010 while our data from Australia spans 2004 through 2010. The span of our data was limited in the Australian case due to the limited availability of data regarding the candidates' ethnic backgrounds. We utilized a variety of sources to code each candidate's ethnic background. In the British case, we rely on a variety of secondary sources noting all ethnic minority candidates at each election (Anwar, 1984; Butler and Kavanagh, 1997; Le Lohé, 1993; Linton, 1987; Norris, 2010). In Australia we utilized candidate profiles from the House of Representatives website to code candidate ethnicity, as well as news reports and archived personal websites, and we focused on immigrant background. A supplementary appendix ${ }^{3}$ is available online detailing the full coding scheme and identifying the source for each ethnic minority candidate.

\subsection{The dependent variable-vote choice}

Our dependent variable is self-reported voting behavior, with 0 being "did not vote" and the other categories representing votes cast for the different available party choices. The slate of party offerings is fairly similar in both countries. The Australian Labor Party and the British Labour Party represent the center-left in each country. Likewise, the Conservative Party represents the center-right in the UK, as does the Liberal-National coalition in Australia. However, there are some slight differences between the party offerings in the two countries. The primary difference is that the Liberal Democrats, a centrist party, is a prominent third party offering in the UK, while the Australian Green Party has become increasingly prominent in Australian politics. The Australian Greens have won seats in both houses of the Australian legislature in recent elections. Table 1 displays the dependent variable coding in each country. ${ }^{4}$

The institutional structure is largely the same in the two countries. Both countries employ single member districts in lower house elections, however the ballot structure is slightly different; Australia employs the alternative vote (AV), where voters list their party preference orderings from first to last, while the UK employs the single 
Table I. Dependent variable by country.

\begin{tabular}{|c|c|c|}
\hline $\begin{array}{l}\text { Dependent } \\
\text { variable }\end{array}$ & Britain & Australia \\
\hline 0 & $\begin{array}{l}\text { Did not vote (base } \\
\text { category) }\end{array}$ & $\begin{array}{l}\text { Did not vote (excluded: } \\
\text { too few observations) }\end{array}$ \\
\hline 1 & Voted Conservative & $\begin{array}{l}\text { Voted Lib-Nat (base } \\
\text { category) }\end{array}$ \\
\hline 2 & Voted Labour & Voted Labor \\
\hline 3 & Voted Lib Dem & Voted Green \\
\hline 4 & $\begin{array}{l}\text { Voted Other (excluded: } \\
\text { too few observations) }\end{array}$ & $\begin{array}{l}\text { Voted Other (excluded: } \\
\text { too few observations) }\end{array}$ \\
\hline
\end{tabular}

non-transferable vote (Cox, 1997). In Australia, the dependent variable was coded as each voter's first preference on the alternative ballot. Another difference between the two countries is that Australia employs the compulsory vote. Over 90 percent of eligible voters actually cast a ballot as a result, thus the number of voters in the ANES survey that did not cast a ballot is trivial and we omit the "did not vote" category from the Australian analysis.

\subsection{Independent variables}

Our key independent variables are respondent ethnicity and candidate ethnicity. Although we provide more detail on specific coding decisions in the supplementary online appendix, we use self-reported racial identity from the BES and self-reported immigration history as the closest equivalent from the AES. For candidates, we use the dichotomous coding scheme of Norris (2010), i.e. ethnic minority (1) or non-ethnic minority (0), in Britain and again take immigration status, i.e. immigrant (1) or nonimmigrant (0), for the Australian counterpart. The Australian coding scheme allows us to cast our net as broadly as possible, including all political candidates who have an immigrant background that they could potentially emphasize during a campaign in order to influence immigrant voters. ${ }^{5}$ Although this coding scheme necessarily captures many different immigrant groups who have different specific representation dynamics (Zingher and Thomas, 2012), this again only increases the probability of a Type II error. We also include a variable in the online appendix for Australia that more closely matched the Norris (2010) scheme for Britain so that, as more data become available, future research can assess this more comprehensively.

What is important to keep in mind with this coding scheme is that it provides for a very tough test of our argument. Theoretically, there is no reason why a South Asian voter would be more likely to support a West Indian candidate, even though they are both coded as ethnic minorities in our analysis. We are comfortable tolerating this potential mismatch between concept and operationalization-our coding scheme introduces a potential source of Type II
Table 2. Descriptive statistics: Sample frequency of respondents.

\begin{tabular}{|c|c|c|c|c|}
\hline & \multicolumn{2}{|c|}{ Britain } & \multicolumn{2}{|c|}{ Australia } \\
\hline & No & Yes & No & Yes \\
\hline Ethnic Minority (EM) & 17,993 & 763 & 3587 & 1179 \\
\hline $\begin{array}{l}\text { Major Left Party Descriptive } \\
\text { Representation (DR Left) }\end{array}$ & 18,192 & 564 & 4305 & 461 \\
\hline $\begin{array}{c}\text { Major Right Party Descriptive } \\
\text { Representation (DR Right) }\end{array}$ & 18,329 & 427 & 4218 & 548 \\
\hline Interaction: DR Left $* \mathrm{EM}$ & 18,706 & 50 & 4624 & 142 \\
\hline Interaction: DR Right * EM & 18,685 & 71 & 4628 & 138 \\
\hline Election years & \multicolumn{2}{|c|}{$\begin{array}{l}1992,1997, \\
2001,2005 \\
2010\end{array}$} & \multicolumn{2}{|c|}{2010} \\
\hline Total observations & 18,756 & & 4766 & \\
\hline
\end{tabular}

error into our analysis, making our hypothesized relationship more difficult to corroborate.

We present descriptive statistics for the variables highlighted above in Table 2. We can see that Britain has comparatively few ethnic minority respondents, and an even smaller minority who live in districts where even one party offers descriptive representation. For example, Labour ran 138 ethnic minority candidates in 99 unique districts over the seven elections in Britain, with the Conservatives running 132 candidates in 105 unique districts. In Australia the numbers are 45 candidates in 25 districts over three elections for Labor, and 48 candidates in 26 districts for the Liberal-National coalition over the same elections. ${ }^{6}$ Although much work needs to be done to understand why these districts in particular attract such candidates, and to understand the extent to which parties take into account the identities of rival candidates in a given district, the first step in understanding the electoral effects of descriptive representation is to examine the relationship of candidates to voters. This makes it doubly important to conduct a comprehensive analysis. It is also worth noting that the numbers of ethnic minority major party candidates (Labour and the Conservatives in Britain, Labour and the Liberal-Nationals in Australia) are low, which comports with other accounts (Saggar, 2000) and helps reinforce the validity of the coding in each country.

In addition to variables for respondent and candidate ethnicity we also include an interaction term between these two variables. It is the interaction between candidate ethnicity and respondent ethnicity that interests us primarily. We are interested in how ethnic minority voters will respond to ethnic minority candidates. This interaction term will allow us to test this conditional effect. The interaction will be equal to one if and only if both the respondent and the candidate are from ethnic minority backgrounds - otherwise the value for the interaction term will be zero. Because multiple parties are capable of running ethnic minority 
candidates in the same district and because the effect of nominating an ethnic minority candidate might vary from party to party, we include one interaction term for each major party.

We include a standard set of demographic and attitudinal control variables on the individual level. We control for party identification, religion, gender, and age. In addition to these individual level controls, we are also able to include macro-level control variables to account for the vote percentages of the various parties over time. It is possible that there is a different baseline probability of supporting a particular party in each district. Moreover, it is also possible that differences in this underlying probability are correlated with the size of the minority population in the district and the ethnicity of the candidates (Sobolweska, 2013: 616). Controlling for the parties' previous share of the vote helps to account for the effect of non-random differences in the level of competitiveness between districts. In order to further account for within-country variation we use year fixed effects that account for election-to-election shifts in aggregate level party support.

We present descriptive statistics for the variables highlighted above in Table 2. We can see that Britain has comparatively few ethnic minority respondents, and an even smaller minority who live in districts where even one party offers descriptive representation. This again highlights the need for an analysis of multiple surveys.

\subsection{Statistical models}

All of the elections in our dataset feature multiple parties, making multinomial logit an attractive specification for our analysis. ${ }^{7}$ Since we are running a multinomial logit on a nominal dependent variable, different coefficients are estimated for $J-1$ categories of the dependent variable, and are displayed below next to the appropriate category. The base category in the UK is not voting, whereas in Australia we use vote for the Liberal-National coalition as the base category. Standard errors are clustered by year. ${ }^{8}$

$$
\operatorname{Pr}\left(Y_{i}=j_{\text {VoteChoice }}\right)=\frac{e^{\beta_{j}^{\prime} X_{i}}}{\sum_{k=0}^{4} e^{\beta_{j}^{\prime} X_{i}}}
$$

\subsection{Results}

We now present the results of two multinomial logit equations predicting voting behavior among respondents in Britain and Australia. The number of categories of the dependent variable, together with a large number of categorical independent variables, means that Table 3 contains a large number of coefficients. We display them for transparency, but move away from this unwieldy format when it comes to interpreting the results. We are particularly interested in whether the interaction terms described above have positive coefficients with respect to the associated party's vote-choice outcome. The coefficients below suggest that this is the case, as the coefficient for the Labour Party in Britain is statistically significant and in the expected direction, and the coefficient for the Labor Party in Australia is in the expected direction.

In order to properly explore these effects we now move to interpreting these non-linear interactive coefficients. We follow Brambor et al.'s (2006) method of interpreting the effect of an interaction term by calculating the marginal effects. Table 3 simulates the estimated effect of "adding" descriptive representation, in a number of different scenarios (all other variables are set to their respective means or modes). For three sets of partisan voters, we show the predicted probability of not voting, or of casting a ballot for Labour, the Conservatives, or the Liberal Democrats respectively. The following tables contain a comparison of the likelihood that a voter will choose any of the four options without descriptive representation and then with descriptive representation. $90 \%$ confidence intervals are included below each predicted probability.

Interpreting the British results first, we begin with the Labour Party and find a statistically and substantively significant effect: approximately a 10-percentage point bump in support among ethnic minority Labour partisans which is statistically significant at the $90 \%$ level. That is, the probability that an ethnic minority Labour partisan will support Labour is 0.80 when a white candidate is on the ballot, opposed to 0.89 percent when an ethnic minority candidate is running in the district. The increase in Labour support is of similar magnitude among ethnic minority independents (from 0.24 to 0.39 ), but the effect just misses hitting traditional levels of statistical significance. ${ }^{9}$ Interestingly, there is a statistically significant decrease in the likelihood that these ethnic minority independents will vote for the Liberal Democratic candidate when Labour runs an ethnic minority candidate in the same district. This suggests that the nomination of ethnic minority candidates can help Labour consolidate support among ethnic minority voters that might otherwise support the Liberal Democrats. This finding in Table 4 thus lays the empirical micro-foundations for arguments about party competition.

With Labour expecting a statistically significant 10 point bump, we next examine the Conservative Party. However, an interesting wrinkle in these findings is that there is never a statistically significant effect on ethnic minority vote choice when the Conservatives nominate an ethnic minority candidate (this is true for both ethnic minorities and whites). The results for Conservatives are shown in Table 5.

This suggests that the effect of descriptive representation might not be independent of party brands. Since we do not have the statistical power to examine Liberal Democrats too, we cannot discern the reason for this lack of effect based on the results of this analysis; however, it is 
Table 3A. British multinomial logit analysis regressing vote choice on candidate ethnicity (base category = did not vote. Year fixed effects included but not shown).

\begin{tabular}{|c|c|c|c|c|c|c|}
\hline \multirow{2}{*}{$\frac{\text { Variables }}{\text { Party ID: Left }}$} & \multicolumn{2}{|c|}{ Conservative } & \multicolumn{2}{|c|}{ Labor } & \multicolumn{2}{|c|}{ Other } \\
\hline & $-1.76 * * *$ & $(0.42)$ & $1.12 * * *$ & $(0.36)$ & -0.31 & $(0.34)$ \\
\hline Party ID: Right & $1.76 * * *$ & $(0.36)$ & $-1.86 * * *$ & $(0.34)$ & -0.52 & $(0.33)$ \\
\hline Party ID: Other & -0.37 & $(0.46)$ & $-0.88 * * *$ & $(0.32)$ & $1.98 * * *$ & $(0.44)$ \\
\hline Party ID: None & $-0.49 * *$ & $(0.25)$ & $-1.22 * * *$ & $(0.21)$ & -0.30 & $(0.27)$ \\
\hline Religion: Protestant & & & & & & \\
\hline Religion: Catholic & $-0.59 * * *$ & $(0.1 I)$ & -0.02 & $(0.1 I)$ & $-0.32 * * *$ & $(0.07)$ \\
\hline Religion: Jewish & -0.33 & $(0.52)$ & 0.15 & $(0.39)$ & -0.32 & $(0.5 I)$ \\
\hline Religion: Muslim & $-0.72^{* * *}$ & $(0.23)$ & 0.16 & $(0.11)$ & 0.07 & $(0.40)$ \\
\hline Religion: Buddhist & $-0.99 *$ & $(0.57)$ & -0.59 & $(0.40)$ & -0.71 & $(0.65)$ \\
\hline Religion: Sikh & 0.35 & $(0.47)$ & -0.03 & $(0.22)$ & 0.00 & $(0.86)$ \\
\hline Religion: Hindu & -0.64 & $(0.73)$ & 0.16 & $(0.42)$ & -0.36 & $(0.45)$ \\
\hline Religion: Atheist & $-0.78^{* * * *}$ & $(0.09)$ & $-0.45^{* * *}$ & $(0.08)$ & $-0.37 * * *$ & $(0.02)$ \\
\hline Religion: Other & $-0.47^{* * * *}$ & $(0.13)$ & $-0.38^{* * *}$ & $(0.14)$ & -0.11 & $(0.10)$ \\
\hline Ethnic Minority & $-0.77^{* * * *}$ & $(0.22)$ & -0.21 & $(0.13)$ & $-0.83 * * *$ & $(0.27)$ \\
\hline Female & -0.03 & $(0.06)$ & 0.05 & $(0.07)$ & -0.01 & $(0.05)$ \\
\hline Age & & & & & & \\
\hline Incumbent: Left & -0.10 & $(0.10)$ & $0.11 *$ & $(0.06)$ & -0.10 & $(0 . I I)$ \\
\hline Incumbent: Right & $-0.28 * *$ & $(0.11)$ & -0.10 & $(0.09)$ & $-0.07 * *$ & $(0.03)$ \\
\hline Vote \%: Right & $0.03 * * *$ & $(0.00)$ & $0.01 * * *$ & $(0.00)$ & 0.01 & $(0.00)$ \\
\hline Vote \%: Left & 0.01 & $(0.01)$ & $0.01 * * *$ & $(0.00)$ & $0.00 * * *$ & $(0.01)$ \\
\hline Vote \%: Other & $0.01 * *$ & $(0.00)$ & 0.00 & $(0.00)$ & $0.04 * * *$ & $(0.00)$ \\
\hline DR: Left & 0.16 & $(0.19)$ & $-0.37 * * *$ & $(0.12)$ & 0.21 & $(0.15)$ \\
\hline DR: Right & $-0.35 * *$ & $(0.14)$ & -0.01 & $(0.22)$ & 0.23 & (0.29) \\
\hline Int: DR Left *EM & -0.38 & $(0.63)$ & $0.85^{* * *}$ & $(0.13)$ & $-1.37 * * *$ & $(0.42)$ \\
\hline Int: DR Right * EM & -0.57 & $(0.91)$ & -0.24 & $(0.36)$ & 0.26 & $(0.23)$ \\
\hline $\begin{array}{l}\text { Constant } \\
N=18756\end{array}$ & $-|.3| * * *$ & $(0.50)$ & $-0.5 I^{* *}$ & $(0.25)$ & $-1.40^{* * *}$ & $(0.47)$ \\
\hline
\end{tabular}

Standard errors in parentheses $* * * p<0.01, *^{*} p<0.05, * p<0.1$.

certainly possibly that the effect of descriptive representation is conditional upon the level of policy congruence between the group and the party offering descriptive representation. Thus, although a reliable 10-percentage point effect is found for some parties, this does not hold for all parties. This finding suggests the need for further research on how descriptive representation interacts with policy congruence.

Having examined the effect of Labour and Conservative nomination strategies on ethnic minority respondents, we now use this same specification to examine the effect that nomination of ethnic minority candidates has on white Britons' voting behavior. When Labour nominates ethnic minority candidates there is an associated decline in support among white Labour partisans. Table 6 demonstrates the existence of a backlash effect; white Labour partisans respond to ethnic minority candidates with a 10percentage point decline in support. We estimate that the likelihood that a white Labour partisan will actually vote for the Labour Party declines from 77 percent to 67 percent when Labour nominates an ethnic minority candidate. This decline in Labour support among whites is associated with a statistically significant increase in white support for the Liberal Democrats. There is almost no effect on white independents or white Conservative partisans, although the probability of voting Labour declines very slightly (but not statistically significantly) in both cases. We find similar results for the Conservatives in Table 7 . The changes for this party are statistically insignificant, unlike the results for Labour partisans, but they suggest the same 10 point drop in partisan support, as white Conservative partisans' probability of voting Conservative drops from almost 0.7 to around 0.6 if the Conservatives run an ethnic minority candidate.

We find a similar pattern of results in Australia, bolstering our findings from the UK. As we show in Table 8, Labor receives just under a 10-percentage point increase in the likelihood that ethnic minority respondents will support when they run an ethnic minority candidate. This effect is statistically significant at the $90 \%$ level. We estimate that the Labor Party also receives a sizeable 17percentage point bump among ethnic minority independents. This increase in support of Labor comes at the expense of a decrease in support for the Green Party. This finding is similar to the British case, where the increase in support for Labour came largely at the expense of the Liberal Democrats. ${ }^{10}$ Another similarity to the British case is that no statistically significant effects for the center-right 
Table 3B. Australian multinomial logit analysis regressing vote choice on candidate ethnicity (base category $=$ Voted Liberal.Year fixed effects included but not shown).

\begin{tabular}{|c|c|c|c|c|}
\hline \multirow{2}{*}{$\frac{\text { Variables }}{\text { Party ID: Left }}$} & \multicolumn{2}{|c|}{ Labor } & \multicolumn{2}{|c|}{ Other } \\
\hline & $2.55^{* * *}$ & $(0.17)$ & $-1.39 * * *$ & $(0.48)$ \\
\hline $\begin{array}{l}\text { Party ID: Right } \\
\text { Party ID: Other }\end{array}$ & $\underline{-3.69 * * *}$ & $(0.27)$ & $-5.66 * * *$ & $(0.65)$ \\
\hline Party ID: None & $-0.33 * *$ & $(0.17)$ & $-2.87 * * *$ & $(0.48)$ \\
\hline Religion: Protestant & 0.06 & $(0.39)$ & -0.11 & $(0.19)$ \\
\hline Religion: Catholic & 0.20 & $(0.20)$ & 0.17 & $(0.25)$ \\
\hline Religion: Jewish & $1.32 * *$ & $(0.64)$ & 0.01 & $(1.09)$ \\
\hline Religion: Muslim & $2.14 * * *$ & $(0.62)$ & $3.21 * * *$ & $(0.68)$ \\
\hline Religion: Buddhist & $0.67 * * *$ & $(0.16)$ & 0.76 & $(1.33)$ \\
\hline Religion: Sikh & & & & \\
\hline Religion: Hindu & 0.24 & $(0.90)$ & 0.19 & $(0.83)$ \\
\hline Religion: Atheist & 0.55 & $(0.46)$ & $0.94 * *$ & $(0.16)$ \\
\hline Religion: Other & & & & \\
\hline Ethnic Minority & $0.16^{* * * *}$ & $(0.06)$ & 0.29 & $(0.24)$ \\
\hline Female & $0.40 * *$ & $(0.17)$ & $0.22 * * *$ & $(0.002)$ \\
\hline Age & -0.0004 & $(0.001)$ & -0.01 & $(0.01)$ \\
\hline Incumbent: Left & $-0.37 * *$ & $(0.18)$ & -0.39 & $(0.13)$ \\
\hline Incumbent: Right & -0.07 & $(0.46)$ & 0.15 & $(0.50)$ \\
\hline Vote \%: Left & 0.02 & $(0.01)$ & -0.02 & $(0.01)$ \\
\hline Vote \%: Right & -0.003 & $(0.02)$ & -0.03 & $(0.01)$ \\
\hline Vote \%: Other & & & & \\
\hline DR: Left & 0.44 & $(0.56)$ & $0.80 * *$ & $(0.37)$ \\
\hline DR: Right & 0.31 & $(0.19)$ & 0.11 & $(0.07)$ \\
\hline Int: DR Left *EM & 0.12 & $(0.80)$ & $-1.66 * * *$ & $(0.26)$ \\
\hline Int: DR Right * EM & -0.34 & $(0.44)$ & $-0.64 * * *$ & $(0.24)$ \\
\hline Year: 2007 & $0.4 I^{* * *}$ & $(0.07)$ & 2.37 & $(0.16)$ \\
\hline Year: 2010 & -0.01 & $(0.05)$ & 2.25 & $(0.10)$ \\
\hline $\begin{array}{l}\text { Constant } \\
N=4766\end{array}$ & -0.71 & $(0.58)$ & 1.53 & $(0.78)$ \\
\hline
\end{tabular}

Standard errors in parentheses $*_{* *} p<0.01,{ }^{* *} p<0.05,{ }^{*} p<0.1$.

(Lib-Nat) party are found, as shown in Table 9. This reinforces the impression that descriptive representation not only has a consistent effect, but that it is also consistently conditional on the party brand.

One important difference between the British and Australian cases is that there is also much less evidence of white backlash against minority candidates in Australia. As Tables 10 and 11 demonstrate, the nomination of ethnic minority candidates does not produce any discernable effect on white voting behavior. The same is true when the Lib-Nats nominate an ethnic minority candidate. The nomination of ethnic minority candidates by the Liberal-National coalition fails to produce a statistically significant effect on either white or ethnic minority voting behavior. One possible explanation for this could be compulsory voting, which means that the portion of the psychological backlash that is translated into abstention in Britain is not translated the same way in Australia.

All of the control variables are in the expected direction in both analyses. Unsurprisingly, voters that identify as a member of a party are significantly more likely to actually vote for the party. Voters that do not identify with a party are more likely to abstain from voting in the British case.

\section{I Discussion}

The preceding analysis has raised several conceptual issues that merit further discussion. We have found strong and consistent evidence that center-left parties can expect around a 10-percentage point bump in ethnic minority partisan support if they nominate an ethnic minority candidate. This is statistically significant in both Britain and Australia. However, one question that analysis raises is: what are the long-term implications of the nomination of ethnic minority candidates? Are they different for different parties? Ethnic and racial minorities often support a particular party at rates higher than socioeconomic variables alone can explain. The gap between a group's socioeconomic status and voting behavior is often attributed to "linked fates" or other explanations focused on the effects of collective identity. But how do groups of voters come to see one party as systematically representing the interests of the group? The nomination of ethnic minority candidates might be part of this explanation. Our analysis demonstrates that ethnic minority voters behave differently when an ethnic minority candidate is on the ballot. Over time it is possible that a party's repeated nomination of ethnic minority candidates could work to forge a link between the group and the party that goes beyond what common policy interests alone can explain. This could also help explain why the effects are greater for center-left parties than center-right parties. It is also worth noting that this basic process could help to explain the attachment between several other types of niche groups (environmentalists, or religious minorities such as Jews) and a particular political party. We believe that the preceding analysis comprehensively demonstrates the usefulness of pursuing this avenue of research.

The fact that the nomination of ethnic minority candidates significantly alters the likelihood that ethnic minorities and whites will support a particular party implies that the decision to nominate an ethnic minority candidate in a given district is not always an easy one. Most theories that attempt to explain party behavior are rooted in the assumption that parties are motivated, at the very least in part, by the desire to maximize the party's share of the vote. Therefore, there is likely an element of strategy guiding each party's decision about when and where to nominate minority candidates. Our analysis established that when center-left parties nominated minority candidates there was a boost in support among minority voters and in some instances there was a backlash by white voters within the district. This finding implies that we should observe parties only nominating minority candidates in districts where the electoral benefits outweigh the potential risks - or in other words, districts with sizeable minority partisan or minority independent populations.

However, we must add some important caveats about out study before moving forward. The conclusions that we are able to draw about the relationship between ethnicity and voting behavior are limited because we were 
Table 4. Predicted probabilities that British Ethnic Minority respondents will support Labour candidates.

Britain: Ethnic Minority respondents and Labour candidates

\begin{tabular}{|c|c|c|c|c|c|c|}
\hline \multirow{2}{*}{$\begin{array}{l}\text { Voters } \\
\text { Candidate }\end{array}$} & \multicolumn{2}{|c|}{ Conservative partisans } & \multicolumn{2}{|c|}{ Independents } & \multicolumn{2}{|c|}{ Labour partisans } \\
\hline & White candidate & EM candidate & White candidate & EM candidate & White candidate & EM candidate \\
\hline \multirow[t]{2}{*}{ PR: Not vote } & 0.16 & 0.19 & 0.39 & 0.40 & 0.13 & 0.09 \\
\hline & $(0.1 I-0.2 I)$ & $(0.04-0.34)$ & $(0.37-0.4 I)$ & $(0.28-0.5 I)$ & $(0.10-0.15)$ & $(0.06-0.12)$ \\
\hline \multirow[t]{2}{*}{ PR: Vote Con } & 0.73 & 0.69 & 0.19 & 0.15 & 0.02 & 0.01 \\
\hline & $(0.66-0.79)$ & $(0.45-0.93)$ & $(0.16-0.21)$ & $(0.02-0.29)$ & $(0.01-0.02)$ & $(0.00-0.02)$ \\
\hline \multirow[t]{2}{*}{ PR: Vote Lab } & 0.05 & 0.10 & 0.24 & 0.39 & 0.80 & 0.89 \\
\hline & $(0.03-0.07)$ & $(0.01-0.19)$ & $(0.19-0.29)$ & $(0.26-0.52)$ & $(0.76-0.84)$ & $(0.86-0.93)$ \\
\hline \multirow[t]{2}{*}{ PR: Vote LD } & 0.06 & 0.02 & 0.18 & 0.06 & 0.06 & 0.01 \\
\hline & $(0.04-0.08)$ & $(0.01-0.03)$ & $(0.12-0.24)$ & $(0.03-0.09)$ & $(0.03-0.08)$ & $(0.01-0.02)$ \\
\hline
\end{tabular}

Table 5. Predicted probabilities that British Ethnic Minority respondents will support Conservative candidates.

\begin{tabular}{|c|c|c|c|c|c|c|}
\hline \multirow{2}{*}{$\begin{array}{l}\text { Voters } \\
\text { Candidate }\end{array}$} & \multicolumn{2}{|c|}{ Conservative partisans } & \multicolumn{2}{|c|}{ Independents } & \multicolumn{2}{|c|}{ Labour partisans } \\
\hline & White candidate & EM candidate & White candidate & EM candidate & White candidate & EM candidate \\
\hline PR: Not vote & $\begin{array}{c}0.40 \\
(0.15-0.65)\end{array}$ & $\begin{array}{c}0.54 \\
(0.4 I-0.67)\end{array}$ & $\begin{array}{c}0.72 \\
(0.55-0.88)\end{array}$ & $\begin{array}{c}0.72 \\
(0.62-0.82)\end{array}$ & $\begin{array}{c}0.41 \\
(0.22-0.60)\end{array}$ & $\begin{array}{c}0.45 \\
(0.25-0.64)\end{array}$ \\
\hline PR: Vote Con & $\begin{array}{c}0.53 \\
(0.29-0.77)\end{array}$ & $\begin{array}{c}0.33 \\
(0.12-0.55)\end{array}$ & $\begin{array}{c}0.10 \\
(0.03-0.17)\end{array}$ & $\begin{array}{l}0.05 \\
(0.00-0.09)\end{array}$ & $\begin{array}{c}0.02 \\
(0.00-0.03)\end{array}$ & $\begin{array}{l}0.01 \\
(0.00-0.02)\end{array}$ \\
\hline PR: Vote Lab & $\begin{array}{c}0.03 \\
(0.02-0.04)\end{array}$ & $\begin{array}{c}0.03 \\
(0.00-0.05)\end{array}$ & $\begin{array}{c}0.09 \\
(0.07-0.11)\end{array}$ & $\begin{array}{l}0.07 \\
(0.03-0.11)\end{array}$ & $\begin{array}{c}0.52 \\
(0.37-0.68)\end{array}$ & $\begin{array}{l}0.45 \\
(0.27-0.62)\end{array}$ \\
\hline PR: Vote LD & $\begin{array}{c}0.04 \\
(0.02-0.07)\end{array}$ & $\begin{array}{c}0.10 \\
(0.00-0.20)\end{array}$ & $\begin{array}{c}0.09 \\
(0.02-0.17)\end{array}$ & $\begin{array}{c}0.16 \\
(0.05-0.27)\end{array}$ & $\begin{array}{c}0.05 \\
(0.01-0.10)\end{array}$ & $\begin{array}{c}0.10 \\
(0.03-0.16)\end{array}$ \\
\hline
\end{tabular}

Table 6. Predicted probabilities that white British respondents will support Labour candidates.

Britain: White respondents and Labour candidates

\begin{tabular}{|c|c|c|c|c|c|c|}
\hline & \multicolumn{2}{|c|}{ Conservative partisans } & \multicolumn{2}{|c|}{ Independents } & \multicolumn{2}{|c|}{ Labour partisans } \\
\hline & White candidate & EM candidate & White candidate & EM candidate & White candidate & EM candidate \\
\hline \multirow[t]{2}{*}{ PR: Not vote } & 0.08 & 0.07 & 0.26 & 0.25 & 0.10 & 0.12 \\
\hline & $(0.06-0.1 I)$ & $(0.05-0.09)$ & $(0.2 I-0.3 I)$ & $(0.22-0.28)$ & $(0.09-0.11)$ & $(0.11-0.14)$ \\
\hline \multirow[t]{2}{*}{ PR: Vote Con } & 0.81 & 0.83 & 0.27 & 0.30 & 0.03 & 0.04 \\
\hline & $(0.78-0.84)$ & $(0.79-0.87)$ & $(0.23-0.31)$ & $(0.25-0.35)$ & $(0.02-0.04)$ & $(0.02-0.06)$ \\
\hline \multirow[t]{2}{*}{ PR: Vote Lab } & 0.03 & 0.01 & 0.20 & 0.13 & 0.77 & 0.67 \\
\hline & $(0.02-0.04)$ & $(0.01-0.03)$ & $(0.16-0.23)$ & $(0.07-0.19)$ & $(0.74-0.80)$ & $(0.60-0.75)$ \\
\hline \multirow[t]{2}{*}{ PR: Vote LD } & 0.07 & 0.08 & 0.27 & 0.32 & 0.10 & 0.16 \\
\hline & $(0.06-0.08)$ & $(0.06-0.09)$ & $(0.23-0.3 I)$ & $(0.22-0.28)$ & $(0.09-0.11)$ & $(0.1 I-0.2 I)$ \\
\hline
\end{tabular}

forced to dichotomize ethnicity into a minority/nonminority category as opposed to looking at each ethnic group individually. The reason why this is important is that it is not clear why a South Asian voter might be more likely to support a West Indian candidate (or vice versa). Our results show a general "representation effect," as ethnic minority candidates tend to perform better amongst ethnic minority voters, but we are unable to tell whether this is the result of increased inter- or intra-group support. Future studies, with larger numbers of ethnic minority voters, will be necessary for disentangling the differences (if any) in how ethnic minority voters respond to ethnic minority candidates from their own group versus candidates from other minority groups. This will be particularly valuable in Australia, where the coding scheme unifies a somewhat wider variety of descriptive representation processes under the heading of "immigrant background", with relatively high profile candidates being foreign-born. The online 
Table 7. Predicted probabilities that white British respondents will support Conservative candidates.

Britain: White respondents and Conservative candidates

\begin{tabular}{|c|c|c|c|c|c|c|}
\hline & \multicolumn{2}{|c|}{ Conservative partisans } & \multicolumn{2}{|c|}{ Independents } & \multicolumn{2}{|c|}{ Labour partisans } \\
\hline & White candidate & EM candidate & White candidate & EM candidate & White candidate & EM candidate \\
\hline \multirow[t]{2}{*}{ PR: Not vote } & 0.24 & 0.29 & 0.57 & 0.57 & 0.34 & 0.34 \\
\hline & $(0.11-0.37)$ & $(0.16-0.42)$ & $(0.43-0.72)$ & $(0.47-0.67)$ & $(0.20-0.48)$ & $(0.24-0.44)$ \\
\hline \multirow[t]{2}{*}{ PR: Vote Con } & 0.68 & 0.60 & 0.17 & 0.12 & 0.03 & 0.02 \\
\hline & $(0.54-0.8 I)$ & $(0.45-0.75)$ & $(0.10-0.24)$ & $(0.06-0.18)$ & $(0.01-0.04)$ & $(0.01-0.03)$ \\
\hline \multirow[t]{2}{*}{ PR: Vote Lab } & 0.02 & 0.02 & 0.09 & 0.09 & 0.53 & 0.52 \\
\hline & $(0.01-0.03)$ & $(0.01-0.04)$ & $(0.08-0.10)$ & $(0.07-0.10)$ & $(0.42-0.64)$ & $(0.42-0.62)$ \\
\hline \multirow[t]{2}{*}{ PR: Vote LD } & 0.06 & 0.09 & 0.17 & 0.21 & 0.10 & 0.12 \\
\hline & $(0.05-0.07)$ & $(0.07-0.1 I)$ & $(0.11-0.24)$ & $(0.16-0.27)$ & $(0.06-0.14)$ & $(0.09-0.15)$ \\
\hline
\end{tabular}

Table 8. Predicted probabilities that Australian immigrant respondents will support Labor candidates.

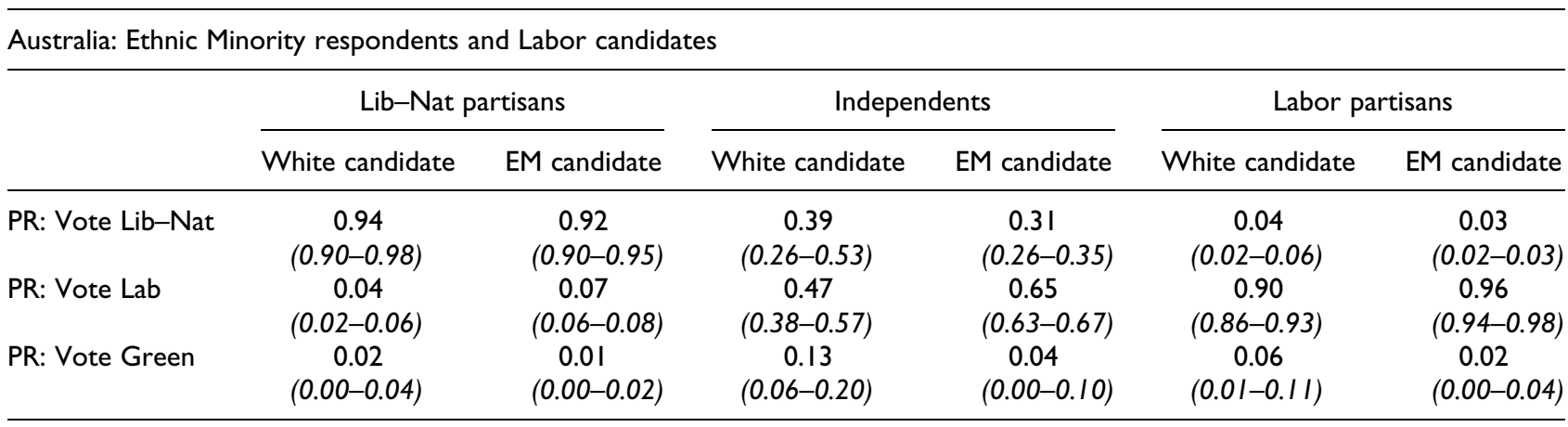

Table 9. Predicted probabilities that Australian immigrant respondents will support Conservative candidates.

Australia: Ethnic Minority respondents and Lib-Nat candidates

\begin{tabular}{|c|c|c|c|c|c|c|}
\hline & \multicolumn{2}{|c|}{ Lib-Nat partisans } & \multicolumn{2}{|c|}{ Independents } & \multicolumn{2}{|c|}{ Labor partisans } \\
\hline & White candidate & EM candidate & White candidate & EM candidate & White candidate & EM candidate \\
\hline \multirow[t]{2}{*}{ PR: Vote Lib-Nat } & 0.96 & 0.96 & 0.48 & 0.50 & 0.06 & 0.06 \\
\hline & $(0.95-0.97)$ & $(0.94-0.99)$ & $(0.45-0.5 I)$ & $(0.37-0.64)$ & $(0.05-0.06)$ & $(0.03-0.09)$ \\
\hline \multirow[t]{2}{*}{ PR: Vote Lab } & 0.03 & 0.03 & 0.43 & 0.44 & 0.89 & 0.91 \\
\hline & $(0.02-0.04)$ & $(0.01-0.05)$ & $(0.40-0.45)$ & $(0.31-0.56)$ & $(0.88-0.91)$ & $(0.87-0.95)$ \\
\hline PR: Vote Green & $\begin{array}{c}0.01 \\
(0.01-0.02)\end{array}$ & $\begin{array}{c}0.01 \\
(0.00-0.01)\end{array}$ & $\begin{array}{c}0.10 \\
(0.07-0.12)\end{array}$ & $\begin{array}{c}0.06 \\
(0.05-0.07)\end{array}$ & $\begin{array}{c}0.05 \\
(0.03-0.06)\end{array}$ & $\begin{array}{c}0.03 \\
(0.01-0.05)\end{array}$ \\
\hline
\end{tabular}

Table 10. Predicted probabilities that native Australian respondents will support Labor candidates.

Australia: White respondents and Labor candidates

\begin{tabular}{|c|c|c|c|c|c|c|}
\hline & \multicolumn{2}{|c|}{ Lib-Nat partisans } & \multicolumn{2}{|c|}{ Independents } & \multicolumn{2}{|c|}{ Labor partisans } \\
\hline & White candidate & EM candidate & White candidate & EM candidate & White candidate & EM candidate \\
\hline PR: Vote Lib-Nat & $\begin{array}{c}0.95 \\
(0.93-0.97)\end{array}$ & $\begin{array}{c}0.92 \\
(0.82-1.00)\end{array}$ & $\begin{array}{c}0.44 \\
(0.33-0.54)\end{array}$ & $\begin{array}{c}0.31 \\
(0.05-0.58)\end{array}$ & $\begin{array}{c}0.05 \\
(0.03-0.07)\end{array}$ & $\begin{array}{c}0.03 \\
(0.00-0.07)\end{array}$ \\
\hline PR: Vote Lab & $\begin{array}{c}0.03 \\
(0.02-0.05)\end{array}$ & $\begin{array}{c}0.05 \\
(0.00-0.11)\end{array}$ & $\begin{array}{c}0.45 \\
(0.36-0.55)\end{array}$ & $\begin{array}{c}0.5 \mathrm{I} \\
(0.24-0.77)\end{array}$ & $\begin{array}{c}0.90 \\
(0.89-0.91)\end{array}$ & $\begin{array}{c}0.89 \\
(0.84-0.94)\end{array}$ \\
\hline PR: Vote Green & $\begin{array}{c}0.01 \\
(0.00-0.03)\end{array}$ & $\begin{array}{c}0.03 \\
(0.00-0.07)\end{array}$ & $\begin{array}{c}0.11 \\
(0.08-0.14)\end{array}$ & $\begin{array}{c}0.18 \\
(0.10-0.26)\end{array}$ & $\begin{array}{c}0.05 \\
(0.03-0.08)\end{array}$ & $\begin{array}{l}0.08 \\
(0.04-0.12)\end{array}$ \\
\hline
\end{tabular}


Table I I. Predicted probabilities that native Australian respondents will support Conservative candidates.

\begin{tabular}{|c|c|c|c|c|c|c|}
\hline & \multicolumn{2}{|c|}{ Lib-Nat partisans } & \multicolumn{2}{|c|}{ Independents } & \multicolumn{2}{|c|}{ Labor partisans } \\
\hline & White candidate & EM candidate & White candidate & EM candidate & White candidate & EM candidate \\
\hline PR: Vote Lib-Nat & $\begin{array}{c}0.97 \\
(0.95-0.98)\end{array}$ & $\begin{array}{c}0.96 \\
(0.94-0.97)\end{array}$ & $\begin{array}{c}0.52 \\
(0.48-0.57)\end{array}$ & $\begin{array}{c}0.45 \\
(0.4 I-0.50)\end{array}$ & $\begin{array}{c}0.07 \\
(0.06-0.07)\end{array}$ & $\begin{array}{c}0.05 \\
(0.04-0.06)\end{array}$ \\
\hline PR: Vote Lab & $\begin{array}{c}0.03 \\
(0.02-0.03)\end{array}$ & $\begin{array}{c}0.03 \\
(0.02-0.05)\end{array}$ & $\begin{array}{c}0.40 \\
(0.36-0.43)\end{array}$ & $\begin{array}{c}0.47 \\
(0.38-0.56)\end{array}$ & $\begin{array}{c}0.90 \\
(0.87-0.91)\end{array}$ & $\begin{array}{c}0.91 \\
(0.89-0.94)\end{array}$ \\
\hline PR: Vote Green & $\begin{array}{c}0.01 \\
(0.00-0.01)\end{array}$ & $\begin{array}{c}0.01 \\
(0.01-0.01)\end{array}$ & $\begin{array}{c}0.08 \\
(0.04-0.12)\end{array}$ & $\begin{array}{c}0.08 \\
(0.03-0.12)\end{array}$ & $\begin{array}{c}0.04 \\
(0.03-0.05)\end{array}$ & $\begin{array}{c}0.04 \\
(0.04-0.06)\end{array}$ \\
\hline
\end{tabular}

appendix helps narrow down these candidates into aboriginal candidates, foreign-born in non-EU and non-English speaking country candidates, and other foreign-born candidates, so as to allow future research to address these questions when more survey data are available. ${ }^{11}$

Another limitation of our current analysis is that it is focused on two cases with similar histories and electoral institutions; we do not explore how institutional differences might affect the relationship between ethnic minority groups, political parties, and descriptive representation. The electoral effect of descriptive representation might be quite different in more proportional electoral systems with larger district magnitudes where party lists are important and there are clearer avenues for small parties to gain representation. One potential avenue for future study could be to analyze the effect that these institutional differences have on the nomination of ethnic minority candidates and to assess whether the electoral effects of nominating minority candidates differ according to the institutional context.

\section{I Conclusions}

Previous research has demonstrated that there is a considerable gap between ethnic minorities' policy preferences and voting behavior. We have argued that descriptive representation explains why this gap remains - at least in part. Collecting data from the UK and Australia, we demonstrate that descriptive representation is consistently associated with around a 10 point bump. This effect was statistically significant for ethnic minority Labour partisans in Britain, and just missed statistical significance for ethnic minority independents in Britain. Our findings in Australia largely mirror our findings in the UK, only we found that the nomination of ethnic minority candidates had an even stronger, and statistically significant, effect on the behavior of ethnic minority independents. Together these results begin to paint an overarching picture of the electoral consequence of descriptive representation. This is an important finding for a number of reasons. First, we show that descriptive representation is a common phenomenon with relatively constant effects, even in vastly different countries and years.
That this can indeed be established empirically illustrates that descriptive representation can be a consistent tool that parties use to win votes. The very consistency of this effect suggests that it can be a powerful tool for winning the longterm loyalty of voters.

\section{Acknowledgements}

The authors would like to thank Hannah Ishmael, Michael McDonald, and participants at the Fordham University political science workshop for their advice, and two anonymous reviewers for their helpful comments.

\section{Funding}

This research received no specific grant from any funding agency in the public, commercial or not-for-profit sectors.

\section{Notes}

1. We examine SMD systems because they are more likely to have smaller party systems and so have more instances of parties attempting to represent multiple ethnic groups, making the potential tradeoff regarding what group to court very clear (Ordeshook and Shvetsova, 1994). We choose Australia and the UK because they both have SMD electoral systems with relatively centralized candidate selection procedures. Other SMD systems, such as the USA and Canada, have similarly electorally important ethnic minorities but have candidate selection systems that are more open (Norris 1997, Norris and Levenduski 1997). In addition, there are also severe data problems with both the USA and Canada, as historical information on candidate ethnicity is missing in many cases.

2. In the absence of an experimental design, we argue that this is the best possible estimate of the effect of descriptive representation. There are only a small number of districts that receive descriptive representation and they are often the districts with the highest concentration of ethnic minority voters. Multiple parties in a country sometimes hone in on such districts, all offering descriptive representation at once. This suggests that many processes are going on at once, and our control variables are unlikely to capture them all. However, an experimental design is not a far-fetched idea in this context. In Britain, new ethnic minority candidates are already assigned haphazardly to one of many impossible-to-win 
seats. In practical terms, it would not be difficult to randomize this process, nor would it be too likely to affect actual democratic outcomes.

3. Available here: https://sites.google.com/a/binghamton.edu/ benfarrer/data.

4. In addition, there are a number of other small parties in both countries. Votes cast for all of these smaller parties are grouped into the "other" parties category due to the small number of responses. Even with this pooling, we were forced to omit the "other" category from both the UK and Australian analyses due to the small number of votes cast for these small parties.

5. The most comprehensive question on ethnic minority status that is asked consistently in the AES is a question about immigrant heritage, but follow-up questions on particular national backgrounds have lower response rates, and so the best available fit capture descriptive representation was between foreign-born respondents and foreign-born candidates. These differences in operationalization are important, and so we run the models separately and interpret the results separately. Similarly, although ideally we would have coded candidate ethnicity in a more nuanced way than simply "white" or "ethnic minority", information beyond this level was often unavailable and the number of observations was too low in any other categories of candidate ethnicity. We obtain almost identical results if immigrants from the UK, Ireland, and New Zealand are excluded.

6. There was a considerably larger number of ethnic minority candidates that ran for office in the 2010 British election. This raises the question of: to what extent is 2010 driving the overall results of the analysis? We assess this question by replicating the analysis on the 2010 subsample and the 1983-2005 subsample. The results of these analyses reveal substantively similar results to the fully pooled analysis, although we find a much weakened effect in 2010.

7. There has been a debate about whether multinomial logit is an appropriate model for capturing vote choice in multiparty elections. This debate is centered on the fact that the multinomial logit specification assumes that the different choices are independent and irrelevant alternatives. One alternative is the multinomial probit model, which does not require the IIA assumption (Alvarez and Nagler, 1998; Glasgow, 2001). We did not use the MNP because it requires information about the parties' positions in policy space in order to assess the substitutability of the choices. By having to make assumptions about where parties fall in policy space, we would be forced to eliminate "did not vote" and the catchall "other parties" categories.

8. A multilevel model would allow us to better measure differences between districts, but for computational reasons we rely on a multinomial logit model and attempt to control for district-level variation as much as possible by using the control variables described above.

9. These findings emerge whether or not the Conservatives are running an ethnic minority candidate in the district.

10. Once again, these findings also emerge if we generate the same predicted probabilities but assume that the Lib-Nat candidate also has an ethnic minority background (but also, once again these findings are less statistically significant). We also find the same results if we run these regressions only using ethnic minority/immigrant respondents.

11. In supplementary analyses using these variables we find similar but weaker results due to the much smaller number of respondents.

\section{References}

Adams J, Merrill S III and Grofman B (2005) A Unified Theory of Party Competition.Cambridge: Cambridge University Press.

Alvarez MR and Nagler J (1998) When politics and models collide: Estimating models of multiparty elections. American Journal of Political Science 42(4): 55-96

Andersen K (1979) The Creation of a Democratic Majority, 1928-1936. Chicago, IL: University of Chicago Press.

Anwar M (1984) Ethnic minorities and the 1983 general election: A research report. London: Commission for Racial Equality.

Arzheimer K and Carter E (2006) Political opportunity structures and right-wing extremist party success. European Journal of Political Research 45(3): 419-433.

Barreto M, Segura GM and Woods ND (2004) The mobilizing effect of majority-minority districts on Latino turnout. American Political Science Review 98(1): 65-75.

Bird K, Saalfeld T and Wust AK (eds) (2010) The Political Representation of Immigrants and Minorities: Voters, Parties and Parliaments in Liberal Democracies. London: Routledge.

Bloemraad I (2006) Becoming a citizen in the United States and Canada: Structured mobilization and immigrant political incorporation. Social Forces 85(2): 667-695.

Bobo L and Gilliam FD Jr (1990) Race, sociopolitical participation, and black empowerment. American Political Science Review 84(2): 377-393.

Brambor T, Clark W and Golder M (2006) Understanding interaction models: Improving empirical analyses. Political Analysis 14(1): 63-82.

Budge I and Farlie DJ (1983) Explaining and Predicting Elections. London: George Allen and Unwin.

Butler D and Kavanagh D (1997) The British General Election of 1997. London: Palgrave Macmillan.

Chong D (1991) Collective Action and the Civil Rights Movement. Chicago, IL: University of Chicago Press.

Chong D and Kim D (2006) The experiences and effects of economic status among racial and ethnic minorities. American Political Science Review 100(3): 335-351.

Chong D and Rogers R (2005) Racial solidarity and political participation. Political Behavior 27(4): 347-374.

Clark CJ (2014) Collective descriptive representation and black voter mobilization in 2008. Political Behavior 36(2): 345-333.

Cox G (1997) Making Votes Count. Cambridge: Cambridge University Press.

Curtice J, Fisher S and Steed M (2005) Appendix 2: The results analysed. In: Kavanagh D and Butler D (eds) The British General Election of 2005. Basingstoke: Palgrave Macmillan, pp. 235-259. 
Dancygier R (2010) Immigration and Conflict in Europe. New York: Cambridge University Press.

Dancygier R and Saunders EN (2006) A new electorate? Comparing preferences and partisanship between immigrants and natives. American Journal of Political Science 50(4): 962-981.

Dawson M (1994) Behind the Mule: Race and Class in African American Politics. New York: Princeton University Press.

Downs A (1957) An Economic Theory of Democracy. New York: Harper and Row.

Ezrow L (2010) Linking Citizens and Parties. Oxford: Oxford University Press.

Fisher SD, Heath AF, Sanders D, et al. (2014) Candidate ethnicity and vote choice in Britain. British Journal of Political Science. DOI:http://dx.doi.org/10.1017/S0007123413000562.

Ford R (2011) Acceptable and unacceptable immigrants: How opposition to immigration in Britain is affected by migrants' region of origin. The Journal of Ethnic and Migration Studies 37(7): 1017-1037.

Franzmann S (2011) Competition, contest, and cooperation: The analytic framework of the issue market. Journal of Theoretical Politics 23(3): 317-343.

Gay C (2001) The Effect of Minority Districts and Minority Representation on Political Participation in California. San Francisco, CA: Public Policy Institute of California.

Geddes A (2003) The Politics of Migration and Immigration in Europe. London: SAGE.

Glasgow G (2001) Mixed logit models for multiparty elections. Political Analysis 9(2): 116-136.

Golder M (2003) Electoral institutions, unemployment and extreme right parties: A correction. British Journal of Political Science 33(3): 525-534.

Griffin JD and Keane M (2006) Descriptive representation and the composition of African American turnout. American Journal of Political Science 50(4): 998-1012.

Heath AF, Fisher SD, Rosenblatt G, et al. (2013) The Political Integration of Ethnic Minorities in Britain. Oxford: Oxford University Press.

Hinich M and Munger MC (1997) Analytical Politics. New York: Cambridge University Press.

Hug S (2001) Altering Party Systems. Ann Arbor, MI: University of Michigan Press.

Jessee SA (2009) Spatial voting in the 2004 presidential election. American Political Science Review 103(1): 59-81.

Jones P (2014) Does the Descriptive Representation of Gender Influence Accountability for Substantive Representation? Gender and Politics 10(2): 175-199.

Le Lohé MJ (1993) Ethnic minority candidates in general elections. Political Quarterly 64(1): 107-117.

Linton M (1987) The colour of your money beats racial prejudice at the polls. The Guardian,19 June.

Mansbridge J (1999) Should blacks represent blacks and women represent women? A contingent 'yes'. The Journal of Politics 61(3): 628-657.

Meguid B (2010) Party Competition between Unequals. Cambridge: Cambridge University Press.
Merrill S III and Grofman B (1999) A Unified Theory of Voting. Cambridge: Cambridge University Press.

Mortimore R (2002) Effect of candidate ethnicity in the British general elections of 1997 and 2001. Available at: www.ipsos-mori. com/newsevents/ca/308/Effect-Of-Candidate-Ethnicity-In-TheBritish-General-Elections-Of-1997-And-2001.aspx.

Mudde C (2007) Populist Radical Right Parties in Europe. Cambridge: Cambridge University Press.

Norris P and Lovenduski J (1997) Political Recruitment: Gender, Race and Class in the British Parliament. Cambridge: Cambridge University Press.

Norris P (ed.) (1997) Passages to Power. Cambridge: Cambridge University Press.

Norris P (2005) Radical Right. New York: Cambridge University Press.

Norris P (2010) The British Parliamentary Constituency Database. Available at: http://www.hks.harvard.edu/fs/pnorris/ Data/Data.htm

Ordeshook PC and Shvetsova OV (1994) Ethnic heterogeneity, district magnitude, and the number of parties. American Journal of Political Science 38(1): 100-123.

Pantoja A, Ramirez R and Segura G (2001) Does ethnicity matter? Descriptive representation in legislatures and political alienation among Latinos. Social Science Quarterly 84(2): 441-460.

Pitkin H (1972) The Concept of Representation. Berkeley, CA: University of California Press.

Preuhs R (2007) Descriptive representation as a mechanism to mitigate policy backlash: Latino incorporation and welfare policy in the American states. Political Research Quarterly 60(2): 277-292.

Saggar S (2000) Race and Representation: Electoral Politics and Ethnic Pluralism in Britain. Manchester: Manchester University Press.

Scherer N and Curry B (2010) Does descriptive representation enhance institutional legitimacy? The case of the U.S. courts. Journal of Politics 72(1): 90-104.

Scheve K and Slaughter M (2001) Labor market competition and individual preferences over immigration policy. The Review of Economics and Statistics 83(1): 133-145.

Simon B and Klandermans B (2001) Politicized collective identity. American Psychologist 56(4): 319-331.

Sobolewska M (2005) Ethnic agenda: Relevance of political attitudes to party choice. Journal of Elections, Public Opinion and Parties 15(2): 197-214.

Sobolewska M (2013) Party strategies and the descriptive representation of ethnic minorities: The 2010 British general election. West European Politics 36(3): 615-633.

Stegmaier M, Lewis-Beck M and Smets K (2013) Standing for Parliament: Do Black, Asian and Minority Ethnic Candidates Pay Extra? Parliamentary Affairs 66: 268-285.

Tate K (2003) Black opinion on the legitimacy of racial redistricting and minority-majority districts. American Political Science Review 97(1): 44-56.

Whitbey KJ (2007) The effect of black descriptive representation on black electoral turnout in the 2004 elections. Social Science Quarterly 88(4): 1010-1023. 
Wolfinger R (1965) The development and persistence of ethnic voting. American Political Science Review 59(4): 896-908.

Wood M, Hales J, Purdon S, et al. (2009) A test for racial discrimination in recruitment practice in British cities. Department for Work and Pensions Research Report 607. Available at: www. natcen.ac.uk/media/20541/test-for-racial-discrimination.pdf.

Zingher JN and Thomas MS (2012) Patterns of immigrant political behaviour in Australia: An analysis of immigrant voting in ethnic context. Australian Journal of Political Science 47(3): 377-397.

\section{Author biographies}

Joshua N Zingher is a postdoctoral fellow at the University of Oklahoma. His research focuses on several aspects of American and comparative politics, including mass political behavior, minority and immigrant politics, and empirical theories of democracy.

Benjamin Farrer is a Visiting Assistant Professor at Hobart and William Smith Colleges, USA. His work focuses on parties and interest groups, particularly those formed by under-represented groups in democratic societies. 